\title{
Social Vulnerabilities and the Community Response. Investing in Social Services and the Sustainability of the Support Provided
}

\author{
Aurelia Oana PÂRVULESCU ${ }^{\star}$
}

\begin{tabular}{l}
\hline \multicolumn{1}{c}{ A R T I C L E I N F O } \\
\hline Article history: \\
Accepted April 2020 \\
Available online May 2020 \\
\hline JEL Classification \\
H55, H50 \\
Keywords: \\
Vulnerability, Social assistance, \\
Social service, Partnership, Needs, \\
Responsibilities, Organization, \\
Beneficiaries
\end{tabular}

\section{Introduction}

According to GO 86/2004 "social services are measures and actions that address social needs of individual, family or group and to prevent and overcome difficult situations, vulnerability and dependence in order to maintain autonomy" to prevent marginalization, social exclusion and improving living standards, they represent "the activities of social workers or other professionals who help people prevent addiction, strengthen family relationships, and restore the social functioning of individuals, families, and communities" (Parker, 1987, p. 154). Social assistance services are an integrated part, in addition to education and health services, of the wider sphere of social services. Social benefits replace the shortage of resources, so social assistance services addressing the deficient capacities, having as main purpose the augmentation, correction and reconstitution of the individual and community capacities necessary for normal life. Social assistance through social services is a component of social protection, represented by the system of social and legal norms with which protection measures are implemented and the provision of social services and benefits to different categories of people at high risk of vulnerability (Cojocaru, 2006).

\section{Organization and functioning of social services}

Social services are provided in various forms in the community when there are different problems and social needs. The organization and functioning of social services is carried out in the public sector, at different levels: central (Government - Ministry of Labor, Social Solidarity and Family); county (County Council); local (Local Council, City Hall); and in the non-governmental sector: non-governmental organizations (foundations, associations). Social services can also be organized in: partnership, which can be of several types: public - non-governmental (for example: DGASPC and an NGO); public - public (for example: DGASPC and a city hall); non-governmental - non-governmental (for example: two foundations / NGOs working together).

The table before is a summary of responsibilities in the organization and functioning of social services and the method of financing (cf. Ordinance 68/2003, as amended by Ordinance 86/2004). The national social assistance and protection system, through the provision of social services, is made up of services and benefits provided for the purpose of human development and the encouragement of individual 
skills, to ensure a minimum level of social welfare as a basis for increasing quality of life and implicitly social inclusion.

Table 1. Responsibilities in the organization and functioning of social services and how to finance

\begin{tabular}{|c|c|c|c|}
\hline $\begin{array}{l}\text { Institution, } \\
\text { organization }\end{array}$ & $\begin{array}{l}\text { Methodological } \\
\text { coordination, } \\
\text { monitoring, } \\
\text { assessment and } \\
\text { control services }\end{array}$ & $\begin{array}{c}\text { Granting of } \\
\text { cash benefits and / or } \\
\text { providing services }\end{array}$ & Financing \\
\hline MMFPS & Yes & No & From the state budget \\
\hline $\begin{array}{l}\text { directions } \\
\text { territorial of } \\
\text { MMFPS }\end{array}$ & Yes & $\begin{array}{l}\text { Information on } \\
\text { social rights; } \\
\text { establishing the right and } \\
\text { payment of money benefits; }\end{array}$ & From the state budget \\
\hline County Council & $\begin{array}{l}\text { General Directorate of } \\
\text { Social Assistance and } \\
\text { Child Protection }\end{array}$ & Yes & $\begin{array}{l}\text { Gives a variety of } \\
\text { specialized services } \\
\text { for children and adults } \\
\text { From the local budget of the } \\
\text { county, } \\
\text { full funding or in } \\
\text { partnership; } \\
\text { Externally funded projects }\end{array}$ \\
\hline Local Council - SPAS & $\begin{array}{l}\text { Administrative control } \\
\text { of local } \\
\text { services }\end{array}$ & $\begin{array}{l}\text { Basic services for children } \\
\text { and adults }\end{array}$ & $\begin{array}{l}\text { From the local budget, wholly } \\
\text { or in partnership, } \\
\text { Externally funded projects }\end{array}$ \\
\hline $\begin{array}{l}\text { Non-governmental } \\
\text { organizations }\end{array}$ & No & $\begin{array}{l}\text { Basic services and } \\
\text { specialized services } \\
\text { for different categories } \\
\text { of beneficiaries }\end{array}$ & $\begin{array}{l}\text { From private donations, } \\
\text { European programs; } \\
\text { From the state budget (local } \\
\text { or central) - public funds by } \\
\text { subcontracting; } \\
\text { In full or in partnership. }\end{array}$ \\
\hline
\end{tabular}

Source: G0 68/2003, amended and supplemented by GO 86/2004

The provision of social services through competent institutions and organizations, have as main mission the promotion and protection of the children rights, adults and the elderly in social risk situation. They aim to support people, groups and communities who are going through a difficult situation and who, due to their limited resources or even lack of them, cannot have access to a minimum standard of living, to ensure their normal functioning from a social and cultural point of view (Verboncu and Zalman, 2005).

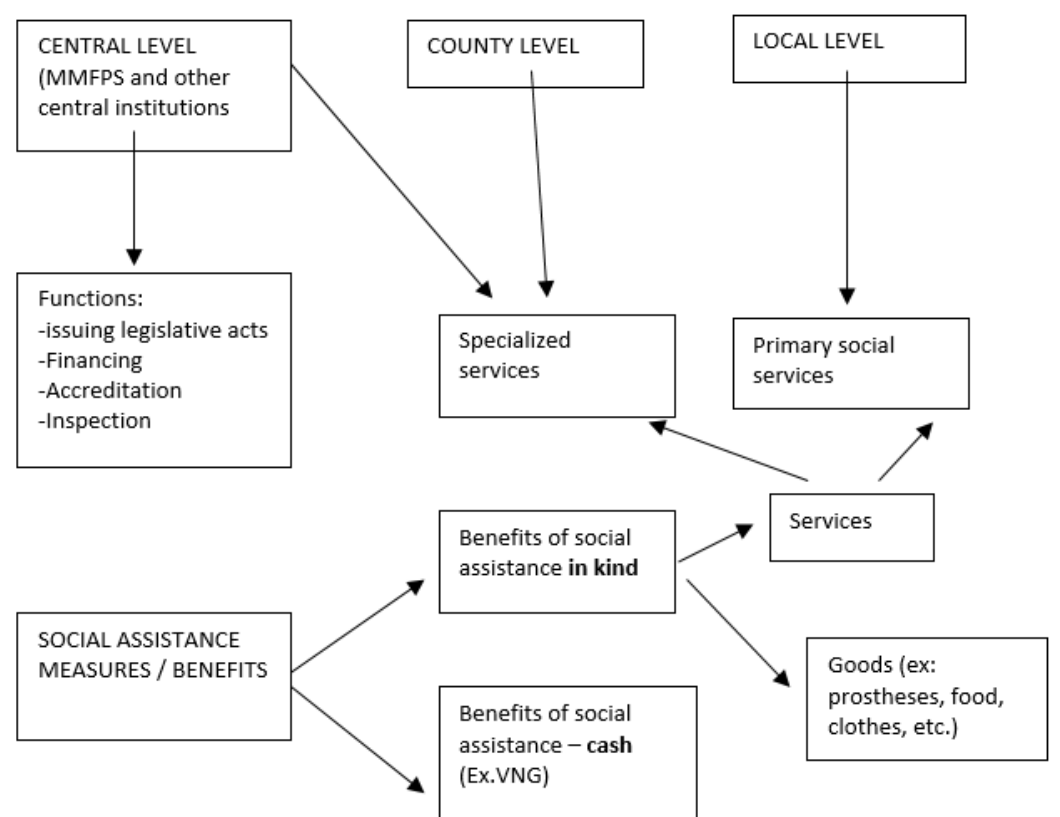

Figure 2. Structure of the public social assistance system (G0 68/2003, amended and supplemented by G0 86/2004) 
As we can see in figure no. 2 the public social assistance system is structured at central, county and local level, the specialized social assistance social services are provided through the central and county system and the primary social services through the local system.

In order to get closer to the needs of the community, the principle of decentralization has emerged, starting from the premise that local public administration authorities are better able to respond to the needs of citizens and have the best ways to solve them. The structure of the public social assistance system is based on social solidarity, transparency, subsidiarity, respect for human dignity, equal opportunities and nondiscrimination, universality, efficiency and effectiveness, proximity and partnership, individual and integrated approach, complementarity, confidentiality, equity and focusing (Buzducea, 2009).

Social assistance services of general interest are organized in various forms, depending on the characteristics of the activities carried out and the particular needs of each category of beneficiaries. They can be granted and organized in an integrated system of employment, social, education, and health services. The classification of social services is based on the following criteria, the purpose of the social service, the category of beneficiaries, the support system, assistance and provision of social services, the place where it is provided, and the legal status of the providers. The purpose of social services is: to support and ensure the basic needs of people, personal recovery and rehabilitation, and personal care services, and social insertion and reintegration services. Accelerating the transfer of economic and administrative skills from the central to the local and regional level, the process of decentralization and deconcentration of public social services were assessed through the instruments of accounting for people's satisfaction with the services provided. On the effective decentralization of local services that include intelligible and diplomatic deployment and that ensure the increase of quality and efficiency of services provided locally, so as to respond to the rigors of the population and their social development. Social services quality is achieved by increasing, supporting and developing the capacity to capitalize on the possibilities of implementing measures, attracting resources, investments for future partnerships in the area of competence of local authorities in the field of social assistance (Cojocaru, 2006).

The organization and functioning of social services is carried out decentralised, at local communities' level of, trying to respond to the identified social needs and taking into account the particular conditions in which the difficult situation manifests itself. Local public administration authorities have the obligation to develop new social services and to diversify the range of social services in order to adapt them to the real needs of the community and to provide in their own budgets the necessary funds for these social services (HG 1826/2005). Depending on the type of provider, organization and functioning of social services are governed by specific laws. The main problems that individuals and communities have to deal with are not only due to the lack of material resources, but also to the lack of their capacities. Often, lack of resources may even be the result of lack of capacity. Therefore, the social assistance services aim at understanding the problems of individuals and groups, the help provided to raise awareness of their own problems, the discovery of effective tools and action procedures for solving these problematic issues. Social assistance and the services it provides are individual therapy, a specific process of social therapy, which is a dynamic approach to social problems, helping individuals and groups to find a solution to overcome problems, thus reducing the risk of social dependence (Ionescu and Trana, 2006).

\section{Social sustainability}

Social service providers may be individuals or legal entities, in turn, legal persons' providers can be public or private depending on subordination and financing. Social service providers ensure, through public administration authorities, the provision of social services, depending on their complexity, educational, medical, housing and employment (Payne, 2012). Social sustainability is often a neglected aspect of sustainability, as discussions on sustainable development often focus on environmental or economic aspects of sustainability. All three dimensions of sustainability must be addressed to achieve the most sustainable results possible. Social sustainability occurs when formal and informal processes, systems, structures and active relationships support the ability of current and future generations to create healthy and viable communities. Sustainable communities are socially equitable, diverse, connected and democratic, and offers a good quality of life. The mental attitude context in which the contemporary man finds himself employed implies, in the first place a modification of the mental attitude of a nature to facilitate - through other concepts than these traditional - the understand in of the new or those to be issued phenomena (Ioan, T., 2013).

Social sustainability is a process of creating sustainable places of success that promote well-being by understanding what people need: the places where they live and work. Social sustainability combines the design of the physical domain with the design of the social world - the infrastructure to support social and cultural life, social facilities, citizen employment systems and space for people and places of evolution. The ability of a community is to develop processes and structures that not only meet the needs of its current members, but also to support the ability of future generations to maintain a healthy community. (Alexiu T., M., Atănăsoaiei, T., 2001). In a democratic state like Romania, sustainable development on social protection is a 
fundamental principle of social, economic and environmental policies, which is achieved by implementing techniques and methods to reduce, prevent and combat the consequences of events considered social risks on the level of individuals, families and community (Zamfir, E., 2002).

Social services are all measures and actions taken to respond to individual, family or community social needs, in order to prevent and deal with situations of social risk, vulnerability or dependency, to preserve autonomy and protection of the person, to prevent marginalization and social exclusion, for the promotion of social inclusion and in order to increase the quality of life (OG 68/2003). Social services have the permanent vocation of the field of intervention, from a dynamic perspective, due to their complexity, social services depend on the field of social protection. The social assistance system, by providing social services and social benefits, were created as a form of active and personalized support and assistance for the beneficiary, family and community in difficulty situations, with an increased high-risk of vulnerability. They intervene to solve potential problems generating marginalization and social exclusion. In Romania, social services have developed mainly in recent years, most social services being developed by institutions and nongovernmental organizations that have taken over models from European countries. As a result, social services are provided according to various methods and procedures. The institutional organization at central level, influenced the elaboration of normative acts, with the regulations that targeted the beneficiaries. At the local level, the structure created for the management and provision of social services are divided according to the central prototype, structured by categories of beneficiaries (Sandu, 2013).

The provision of social services is based on principles that govern them, such as: social solidarity, family and community, community organization, partnership and collaboration, complementarity, teamwork, diversification of activities as resources increase (Law no. 292/2011). The organizational structure of the provision of social services is essential for the good performance of the services provided and for the safety of their beneficiaries. If social legislation and policies are not respected, then the mission of the structure may fail, not only of the institutions or organizations, but also of the purpose of solving the beneficiaries problems. Promote the decentralization process, bringing substantial decision-making and service delivery on the needs of families and communities and emphasizing the role of local authorities with potential benefits. In order to achieve these aspects, the state seeks to assume responsibilities for the implementation of social assistance measures in accordance with special laws and to ensure the transfer of responsibilities and financial resources to local public administration authorities, public services, decentralized and civil society. The elaboration and application of national development policies are mandatory, giving the possibility of the consequent extension of the well-being of the whole society, of the entire people, not being discriminated socially or medically (Buzducea, 2009).

\section{Types of social services}

Social assistance services are classified into: primary social services, which have a general character and aim at preventing or limiting situations of difficulty or vulnerability. Primary social services are provided primarily in the community, meaning beneficiaries or users receive assistance when needed, but remain in their family and continue to live in their home (Moore, 1993). Primary social services in the community are granted to all beneficiaries, in order to prevent and reduce situations of difficulty or at high risk of marginalization and social exclusion (Howe, 2001).

Specialized social services aim to maintain, restore or develop the social functioning capacity of individuals and families. Specialized social services are granted in special cases considered rather exceptional, people in difficulty are placed in service residential types / institutional (Zamfir, 2002). Specialized social services are services that include the mobilization of specialists in order to maintain, rehabilitate, and develop personal, individual skills in order to overcome situations of vulnerability in which beneficiaries and their families may be (Bocancea and Neamțu, 1999).

Social - medical care services are specialized social services for the elderly, the disabled, the chronically ill, people suffering from incurable diseases, children with special needs, people victims of domestic violence (OG 68/2003). Medical care social services are services provided in one of the residential institutions or in specialized temporary placement institutions, which require the granting of a series of complex interventions that include a combination of specialized social services provided to those people with increased dependence and who need permanent supervision (Zamfir, Stănescu and Arpinte, 2015).

Table 2. Types of social services

\begin{tabular}{|l|l|}
\hline \multicolumn{1}{|c|}{ Service type } & \multicolumn{1}{c|}{ Their content } \\
\hline PRIMARY SERVICES & $\begin{array}{l}\text { Activities for identifying individual, family and group social needs; if } \\
\text { necessary, sending the person or family to specialized services; }\end{array}$ \\
\cline { 2 - 3 } & Information activities on social rights and obligations of beneficiaries; \\
\cline { 2 - 2 } & Measures and emergency action in crisis situations; \\
\cline { 2 - 2 } & $\begin{array}{l}\text { Measures and actions to maintain the person in a difficult situation in the } \\
\text { family and community; }\end{array}$ \\
\hline
\end{tabular}




\begin{tabular}{|c|c|}
\hline Service type & Their content \\
\hline & Primary counseling activities; \\
\hline & Organizational and community development activities; \\
\hline & Actions to raise awareness of local public opinion; \\
\hline & Collaborative actions with other services. \\
\hline \multirow{9}{*}{$\begin{array}{l}\text { SPECIALIZED } \\
\text { SERVICES }\end{array}$} & Recovery and rehabilitation; \\
\hline & Support and assistance to families and children in need; \\
\hline & Support and assistance for the elderly; \\
\hline & $\begin{array}{l}\text { Extracurricular informal education for children and adults, according to the } \\
\text { need of each category; }\end{array}$ \\
\hline & $\begin{array}{l}\text { Support and guidance for integration, rehabilitation and vocational re- } \\
\text { education; }\end{array}$ \\
\hline & $\begin{array}{l}\text { Support and assistance for people with disabilities, drug addicts, victims of } \\
\text { domestic violence, victims of human trafficking, etc .; }\end{array}$ \\
\hline & Social mediation; \\
\hline & Institutional counseling, in information and counseling centers; \\
\hline & $\begin{array}{l}\text { Medical and social care for people in a situation of total or partial } \\
\text { dependence due to age, disability, chronic diseases or incurable diseases. }\end{array}$ \\
\hline \multirow[t]{3}{*}{$\begin{array}{l}\text { SOCIAL-MEDICAL } \\
\text { CARE SERVICES }\end{array}$} & $\begin{array}{l}\text { Basic services: support for personal hygiene, dressing and undressing, } \\
\text { hygiene disposal, nutrition and hydration, transfer and mobilization } \\
\text { movement inside, communication; }\end{array}$ \\
\hline & $\begin{array}{l}\text { Support services: food preparation or delivery assistance, shopping, } \\
\text { housekeeping, transportation, companionship, administration and } \\
\text { management activities, leisure activities; }\end{array}$ \\
\hline & $\begin{array}{l}\text { Rehabilitation services and adaptation to the environment: small design, } \\
\text { repairs and the like. }\end{array}$ \\
\hline
\end{tabular}

Depending on the type of beneficiaries, there are specialized units that provide specific social services adapted to the needs of the beneficiaries. These services are developed at the community level by social needs identified and proposals set out in the strategic and planning documents. (HG 797/2017). An assessment of the situation and social needs can help identify intervention strategies to highlight the relationship between intervention and effects, an understanding of mechanisms and contexts that help to achieve relevant results (Cojocaru, S., 2010). At the same time, the precise establishment of the diagnosis of needs and directions of action ensures a transparent approach to the management and provision of social services and benefits. (Zamfir, Stănescu and Arpinte, 2015). Social services are expressed through social protection system components, the objective of which is proposed in attention processes of social inclusion. The national strategy for the development of the social assistance system is based on the principles underlying and administered by the construction of the social services system: social solidarity, respect for human dignity, proximity, equality and non-discrimination, freedom of choice, public accountability and transparency, promoting personal autonomy, facilitating access to social assistance and care services, partnership, multidisciplinary approach, confidentiality, complementarity and integrated approach. The challenges facing the social services system are related to the possibility of providing care services, satisfactory and of specific quality value, competent to respond to the needs of the increased number of vulnerable people. Ensuring the quality of social services is the process of development and organizational improvement, built on the strengths of the institution and its good practice, by implementing techniques and methods for systematic development and discipline of social work. It also includes the organized identification of the purpose and aspirations of the services regarding the quality of the service and its monitoring. The standards that apply and the tools that are used for the implementation and planning of the dynamic, continuous process of increasing the quality of social services (Cojocaru, 2010).

\section{Conclusions}

In conclusion, social work has changed significantly and processes have been recorded to help vulnerable people, further through social services and benefits. However, the profession needs a greater voice to express the problems faced, obtaining thus an additional help to ensure that beneficiaries are part of quality social services. Service recipients have more rights and freedoms, although there are branches that need to focus on improving the services available and those offered. (Mărginean and Bălașa, 2002).

\section{References}

1. Achiței, A., Amarii, M., Anghelina, M., Brumă, V., Cojocaru, Ș., Costache, L., Cucli-Iane, D., Mocanu, E., Necula, R., Neguțu, N., Poenăreanu, S., \& Tăbușcă, D., (2002). Ghidul practicianului în asistența socială pentru copil și familie. Intervenția în criză. Metodologie, Standarde, Proceduri. În Holt Romania, Ghiduri de bună practică în asistența socială a copilului și familiei (pp. 13-91). Iași: Editura Lumen. 
2. Bocancea, C., Neamțu, G., 1999, Elemente de asistență socială, Editura Polirom, Iași.

3. Buzducea, D., 2005, Aspecte contemporane în asistența socială, Editura Polirom, Iași;

4. Buzducea, D., 2009, Sisteme moderne de asistenţă socială. Tendinţe globale şi practici locale, Editura Polirom, Iaşi.

5. Buzducea, D., (coord.), 2010, Asistența socială a grupurilor de risc, Editura Polirom, Iași.

6. Buzducea, D., (coord.), 2013, Economia socială a grupurilor vulnerabile, Editura Polirom, Iași.

7. Buzducea, D., 2017, Asistenta socială. Compediu de istorie, teorie si practică, Editura Polirom, Iasi.

8. Cojocaru, S., 2005, Metode Apreciative în Asistența Socială. Ancheta, Supervizarea și Managementul de Caz, Editura Polirom, Iași.

9. Cojocaru, S., 2006, Proiectul de intervenție în asistența socială. De la propunerea de finanțare la proiectele individualizate de intervenție, Editura Polirom, Iași.

10. Cojocaru, S., 2010, Evaluarea programelor de asistență socială, Editura Polirom, Iași.

11. Ioan, T., 2013, Culture, resonance space of the change in contemporary Europ, 3rd World Conference on Learning, Teaching and Educational Leadership (WCLTA-2012) Procedia - Social and Behavioral Sciences, Volume 93, 21 October 2013, Pages 709-713, http://www.sciencedirect.com/science/article/pii/S1877042813033697

12. Ionescu, L., Trană, D., M., 2006, Managementul financiar-contabil în administraţia publică, Editura Cartea Universitară, Bucureşti.

13. Howe, D., 2001, Introducere în teoria asistenței sociale, Editura MarLink, București;

14. Mărginean, I., Bălașa, A., (coord.), 2002, Calitatea vieții în România, Editura Expert, București.

15. Osvat, C., \& Makai-Dimeny, J., (2013). The use of the systemic theory in social intervention when working with families facing difficulties. In Runcan, P. L., Rață, G., Cojocaru, S., (coord.). Applied Social Sciences. Social Work, Cambridge Scholars Publishing, UK., pp. 233-241; ISBN: 13: 978-1-4438-4329-4. 1-4438-4329-6, http://www.cambridgescholars.com/download/sample/57851;

16. Payne, M., 2012, Teoria modernă a asistenței sociale, Editura Polirom, Iași.

17. Preda, M., 2002, Politica socială românească între sărăcie și globalizare, Editura Polirom, Iași.

18. Preda, M., (coord.), 2009, Riscuri și inechităţi sociale în România, Editura Polirom, Iași.

19. Rujoiu, V., Rujoiu, O., (coord.), 2012, Violența în familie. Între percepție socială și asumare individuală, Editura ASE, București.

20. Sandu, A., 2013, Asistența socială aplicată. Tehnici de cercetare și modele de intervenție, Editura Lumen, Iași.

21. Verboncu., I., Zalman, M., 2005, Management și performanţe, Editura Universitară, București.

22. Vîrjan, D, (2012). Economia şi protecția socială în relaţie cu sărăcia. Date și opinii. Revista de Economie Socială, vol. II, nr. 3 (2012), pp. 115-27, http://profitpentruoameni.ro/wp-content/uploads/2013/05/04-economia-si-protectia-sociala-in-relatie-cu-saracia.-date-siopinii.pdf.

23. Zakour, D., Gillespie, M., 2013, Community Disaster Vulnerability. Theory, Research and Practice, Springer, New York, Library of Congress.

24. Zamfir, C., Stănescu, S., 2007, Enciclopedia Dezvoltării Sociale, Editura Polirom, Iaşi.

25. Zamfir, E., (coord.), 2000, Strategii Antisărăcie și Dezvoltare Comunitară, Editura Expert, București.

26. Zamfir, E., Stănescu, S., M., Arpinte, D., 2015, Asistența socială în România după 25 de ani: Răspuns la problemele tranziției, Editura Eikon, Cluj-Napoca.

27. HG $1826 / 2005$

28. $H G 797 / 2017$

29. Legea $\mathrm{nr}$. $292 / 2011$

30. OG 68/2003, modificată şi completată de OG 86/2004 